\title{
Two Concepts on the Immunological Aspect of Blastocyst Implantation
}

\author{
Koji YOSHINAGA ${ }^{1)}$ \\ 1) Reproductive Sciences Branch, NICHD, NIH, DHHS, Maryland 20892-7510, USA
}

\begin{abstract}
The process of blastocyst implantation is a series of interactions between the blastocyst and maternal tissues. The purpose of this process is (1) to provide nourishment to the embryo for developmental growth in appropriate physiological and endocrinological environment until a placenta is established, and (2) to protect the (semi-)allogeneic embryo from any attacks from the maternal immune system. To facilitate successful implantation, therefore, these two aspects of the embryonic demand must be satisfied in the embryo-maternal interface throughout the entire process of implantation. The first concept I present in this paper is that blastocyst implantation essential factors (BIEFs) have dual functions: one, for structural and functional modification of the endometrium to accommodate the developing embryo and provide nourishment and suitable environment for its development, and the other, for modulation, directly or indirectly, of the maternal immune system to prevent attacks by the maternal immune system. The second concept is that BIEFs convert the endometrium (or uterus) from an immunologically non-privileged site to a privileged site. This endometrial (uterine) conversion is the immunological aspect of the blastocyst implantation process. When the endometrium has become receptive for blastocyst implantation, it signifies that the immunological conversion of the endometrium by BIEFs has been sufficiently attained to let the embryo start contacting maternal tissues. During the early stages of placentation, as the trophoblast cells differentiate and make their way to the maternal blood vessels to establish the placenta, BIEFs continuously provide nourishment and immunological protection to the developing embryo. The immunological protection of the embryo/fetus from potential attacks by the maternal immune system appears to reach a peak at the time of establishment of the placenta. Thus, clarification of the roles of BIEFs in both the physiological/endocrinological aspect as well as the immunological aspect is essential for understanding the biological process of implantation.
\end{abstract}

Key words: Blastocyst implantation, Concepts, Immune aspect

(J. Reprod. Dev. 58: 196-203, 2012)

$\mathbf{H}$ istorically the research on blastocyst implantation has progressed in parallel with the development of endocrinology and, thus, studies on hormonal requirements and hormone action mechanisms in implantation have been usual approaches in studying implantation. Although these studies revealed many useful pieces of information, the current knowledge is insufficient to understand the infertility due to implantation failure, to diagnose the cause of it, and to find its treatment. One of the reasons of insufficiency of our knowledge is lack of a multi-disciplinary approach to understand a series of very complicated biological processes, particularly to consider the process in endocrinological as well as immunological points of view. As the first step to solve this problem, I believe that it is important, that researchers consider immune cells in the trophoblast-maternal tissue interface in the research on blastocyst implantation. To achieve this approach, one has to focus on each step of the implantation process and identify what cells are involved in that selected step. This concept that immune cells are indispensable in the process of implantation is based on the following two concepts: (1) BIEFs have dual functions, the one, physiological/endocrinological, and the other, immunological, and (2) immunological aspect of implantation process is the conversion process of the endometrium (uterus) from non-immunologically

Received: November 16, 2011

Accepted: November 29, 2011

(C)2012 by the Society for Reproduction and Development

Correspondence: K Yoshinaga (e-mail:ky6a@nih.gov) privileged site to immunologically privileged site. The following is a collection of research reports that support these concepts:

\section{Concept 1: BIEFs Have Dual Functions, The One, Physiological/Endocrinological, and The Other, Immunological}

This first concept is based on the finding that most of the molecules essential for blastocyst implantation are immunomodulators [1]. Here I will elaborate on the dual functions of several examples of BIEFs, i.e., progesterone, trophoblast gonadotropins, leukemia inhibitory factor, prostaglandin $\mathrm{E}_{2}$, and anandamide.

\section{Progesterone (P4)}

Physiological/endocrinological function: P4 is an essential steroid of pregnancy. P4 inhibits estrogen-stimulated proliferation of glandular epithelium. P4 stimulates proliferation of decidual cells. P4 stimulates production of uteroglobin by the rabbit uterus, and glycodelin by primate uterus. Physiological/endocrinological actions of P4 in detail are referred to the articles by Graham and Clarke [2], Spencer \& Bazer [3], and Large \& Demayo [4]. P4 acts on the endometrial tissues, however, it is necessary that the endometrium must be continuously exposed to P4 for at least $48 \mathrm{~h}$ to render it receptive for implantation together with a small dose of estrogen at the end of this P4-priming period in case of some small rodents such as rats and mice [5]. While it takes $6-7 \mathrm{~h}$ for estrogen to induce receptivity in the $\mathrm{P} 4$-primed endometrium $[5,6], 48 \mathrm{~h}$ 
during which $\mathrm{P} 4$ necessitates its action must include targets beyond a single gene expression by a nuclear receptor binding to the DNA. It appears that "P4-priming" needs many complex processes such as cellular modification, expressions of essential genes, and many steps that may involve organs other than the uterus. Effects of P4 on the luminal epithelium and stromal cells have been studied to understand the uterine receptivity and decidualization. P4 also stimulates glandular epithelium for the production of "uterine milk" to nurse the embryo between initial attachment through establishment of placenta in most of ruminants

Immunological function: Daynes et al. [7] reported that locally active steroid hormones may facilitate compartmentalization of immunity by regulating the types of lymphokines produced by helper T cells. Piccinni et al. [8] studied the effects of P4 on cytokine production and found that $\mathrm{P} 4$ favors production of $\mathrm{Th}-2$ type cytokines which have been implied in fetal allograft survival and maintenance of successful pregnancy. P4 not only affects cytokine production, but it affects $\mathrm{T}$ cell differentiation in favor of Th-2 type [9]. Dosiou et al. [10] studied membrane receptors of human lymphocytes and found the newly characterized membrane progesterone receptor $\alpha(\mathrm{mPR} \alpha)$ and $\mathrm{mPR} \beta$ are expressed on peripheral blood lymphocytes specifically by $\mathrm{T}$ lymphocytes. The expression of $\mathrm{mPR} \alpha$ appears to be hormonally regulated in $\mathrm{CD}^{+}$ T lymphocytes, but not in $\mathrm{CD}^{+} \mathrm{T}$ lymphocytes with high $\mathrm{P} 4$ state. These researchers found that $\mathrm{mPRs}$ are expressed in the human immune system and mediate $\mathrm{P} 4$ activation of $\mathrm{G}_{\mathrm{i}}$-proteins. These reports indicate that the post-ovulatory activated luteal function converts the female (maternal) immune system by means of P4 to be ready for not rejecting the expected foreign conceptus by $\mathrm{T}$ cells. P4 not only directs the immune system, but also converts the uterine function physiologically/endocrinologically to prepare its cells to accept the foreign conceptus by surrounding with specialized cells that secrete molecules which convert the immune cells to protect the invading and growing conceptus. There have been reports on P4-induced blocking factor (PIBF). This factor appears to play a role in mediating $\mathrm{P} 4$ effect on regulation of decidual lymphocyte cytotoxic activity at the maternal-fetal interface [11].

\section{Trophoblastic hormones: Chorionic gonadotropins (CGs), Interferon-tau (IFN- $\tau)$}

Physiological/endocrinological function: Hirose [12] first found human placenta produces proteinaceous hormone that stimulates the ovary to produce corpora lutea. Since hCG binds LH receptors, it stimulates secretion of progesterone from the corpus luteum [13]; hCG promotes the differentiation of cytotrophoblasts into syncytiotrophoblast [14], and incubation of human cytotrophoblast cells with hCG significantly increased VEGF secretion [15]. hCG contributes to endothelial cell recruitment and vessel formation, thus, it plays a key role by increasing the uterine blood flow through vasodilation and angiogenesis [16]; hCG can regulate the synthesis of prostaglandins [17], and cAMP formation [18]. One of the hCG roles in enhancing implantation was suggested by Herrmann-Lavoie et al.[19] is that hCG down-regulates expression of a decoy IL-1 receptor (IL-1R2), and effectively IL-1 (an embryonic signal) can activate IL-1R1 on the endometrial epithelium for successful implantation. hCG stimulates secretion of LIF by endometrial epithelial cells [20]. The gonadotropin which is present in high concentration in the blood of early pregnant mare (pregnant mare's serum gonadotropin, PMSG [21]) is of chorionic origin and is named eCG [23]. Mare pregnancy is dependent on luteal progesterone and placental progesterone does not replace the ovarian progesterone until later than day 80 of gestation [22, 23]. eCG has been studied for its stimulatory effect on the ovarian function and little information is available on direct effect on the uterus.

Interferon-tau belongs to another category of trophoblast hormones mainly found in ruminants and pigs. Moor and Rowson [24] found that the presence of the embryo in the uterus between the $12^{\text {th }}$ and $13^{\text {th }}$ day after estrus is essential for the maintenance of the corpus luteum of pregnancy. It was found that the life span of corpora lutea is prolonged by developing conceptus in sheep and it was confirmed by infusion of embryonic tissue homogenate into the uterus, and the active substance is inactivated by heat, and the older embryos did not have the antiluteolytic activity [25]. Subsequently the active molecule was given various names by different investigators, and Imakawa et al. [26] identified the molecule as most probably as an interferon-alpha. Later, the investigators in this field decided to adopt the terminology interferon-tau (IFN- $\tau$ ) to name the interferons produced by the preimplantation ruminant conceptus to distinguish it from the related IFN- $\alpha,-\beta$, and- $\omega$ [27]. IFN- $\tau$ is considered to act on the endometrial epithelium to block the release of prostaglandin $F_{2} \alpha$, a potent luteolytic factor [28]. IFN- $\tau$ or progesterone induces expression and secretion of osteopontin by uterine glands during the periimplantation period and that osteopontin may induce adhesion between luminal epithelium and trophectoderm to facilitate superficial implantation [29].

Immunological function: hCG contributes to maternal immunotolerance and endometrial apoptosis by regulating the Fas-Fasligand system. Kayisli et al. [30] observed that increased apoptosis in human endometrium coincides with the implantation window. hCG treatment decreased cell proliferation and increased apoptosis in endometrium. There is more decidual apoptosis near invading interstitial cytotrophoblasts than in deciduas without interstitial cytotrophoblasts. They observed high hCG levels coinciding with the development of peritrophoblastic immune tolerance. In human endometrial epithelial cell culture hCG increased secretion of LIF, but it reduced IL-6 secretion. Since LIF is a pro-implantation molecule and IL-6 is a pro-inflammatory molecule, hCG facilitates successful implantation through these molecules [20]. hCG induces synthesis and secretion of macrophage migration inhibitory factor (MIF) by endometrial stromal cells, and MIF has proangiogenic and immune-modulatory effects, hCG appears to modulate immune response through this mediator [31]. hCG also stimulates IFN $\gamma$-primed macrophages to increase production of reactive oxygen, IL-6, IL-12p40 and enhanced phagocytosis of apoptotic cells [32]. Ueno et al. [33] treated autoimmune diabetic mice with hCG and found that hCG-induced upregulation of indoleamine 2,3 , dioxygenase in dendritic cells plays a major role in pregnancy associated resistance to autoimmunity. Lei et al. [34] found hCG can upregulate human trophoblast indoleamine 2,3-dioxygenase. This enzyme breaks tryptophan down to $\mathrm{N}$-formylkynurenine, and prevents the activation of lymphocytes. Wan et al. [35] hypothesized that hCG is involved in the maternal-fetal immune tolerance by 
the regulation of dendritic cell function. They showed that hCG decreased cytokine production by dendritic cells and inhibited the ability of dendritic cells to stimulate $\mathrm{T}$ cell proliferation. Thus, hCG contributes to the maternal-fetal tolerance during pregnancy by modifying dendritic cells toward a tolerogenic phenotype. Uterine natural killer ( $\mathrm{uNK}$ ) cells in the endometrium play a key role in establishment of successful pregnancy. Proliferation of these uNK cells is regulated by hCG via mannose receptor, not LH-receptor, on uNK cells [36].

Emond et al. [37] examined effects of IFN- $\tau$ on uterine cells and found that IFN- $\tau$ stimulates both leukocytes and endometrial stromal cells to express granulocyte-macrophage colony stimulating factor (GM-CSF). Since GM-CSF has been shown to stimulate trophoblast differentiation and secretory activity of placental peptides (CG and PL) [38], IFN- $\tau$ provides beneficial cytokines to the feto-maternal interface. Emond et al. [39] found IFN- $\tau$ stimulates maternal epithelial expression of cyclooxygenase-2 (COX-2) as well as MG-SCF during the peri-attachment period in the cow. Since increase in COX-2 is related to increase in $\mathrm{PGE}_{2}, \mathrm{PGF}_{2 \alpha}$, in the endometrium, Since GM-CSF has been reported to promote development of in vitro produced bovine embryos [40], IFN- $\tau$ enhances embryonic development through these intermediate molecules.

\section{Leukemia Inhibitory Factor (LIF)}

Physiological/endocrinological function: Implantation of blastocysts fails in LIF knock-out mice [41], and LIF is expressed in the endometrial glands just before implantation as a result of preimplantation increase in estrogen [42]. LIF is needed to express cyclooxygenase-2 (COX-2) and heparin-binding EGF-like growth factor (HB-EGF) in the uterus. COX-2 serves the synthesis of prostaglandins. LIF, thus, prepares the endometrium to render it receptive and LIF again is expressed around the blastocyst at the time of attachment, suggesting that LIF serves in the adhesion of the trophoblast to the luminal epithelium. LIF stimulates Stat3 phosphorylation and translocation of Stat 3 to the nucleus acts as a transcription activator. This LIF action is temporarily regulated on day 4 (just before implantation), and Stat 3 translocation to the nucleus does not take place on Day3 or 5 [43]. Arici et al. [44] and Aghajanova et al. [45] thought timing of LIF expression in the human endometrium suggests its important role in implantation. Marwood et al. [46] showed the attachment of human endometrial epithelial cells to fibronectin and collagen IV was stimulated by LIF and IL-11, and Stat3 is involved in this adhesion mechanism. LIF receptor signaling (LIF-JAK1-SOCS3) is an essential pathway for the regulation of trophoblast giant cell differentiation [47].

Immunological function: In her review on LIF in implantation and uterine biology, Kimber [48] addressed important roles of LIF on the luminal epithelium and stromal decidualization. She also addressed its influence on leukocytes. Schofield \& Kimber [49] examined several subpopulations of leukocytes in the mouse uterus during early pregnancy: they found the percentage of macrophages was reduced by more than half in the LIF knock-out mice on Day 3 of pregnancy and their distribution was disrupted, suggesting LIF is a chemokine in the mouse. Metcalfe et al. [50] studied molecules that are involved in regulation of transplantation tolerance. They found that distinguishing features of allo-tolerance were Foxp3 protein expression, LIF release and increased levels of STAT3. Human Leukocyte Antigen Type G (HLA-G) molecules are non-classical I MHC molecules specifically expressed by human cytotrophoblast cells of early placenta that have been suggested to play a role in facilitating the immune tolerance of the conceptus [51]. Bamberger et al. [52] examined if LIF would act as promoter of HLA-G and confirmed that LIF plays a role in modulating HLA-G production.

\section{Prostaglandin $E_{2}$}

Physiological/endocrinological function: One of the initial uterine reactions to implanting embryos in small rodents is an increase in capillary permeability, and Kennedy [53] suggested that prostaglandins are involved in the increase in capillary permeability and subsequent implantation. $\mathrm{PGE}_{2}$ enhances human endometrial stromal cell differentiation and prolactin production [54]. Among prostaglandins $\mathrm{PGE}_{2}$ is considered especially important for implantation and decidualization [55]. $\mathrm{PGE}_{2}$ exerts its effects by binding one of 4 receptors, $\mathrm{EP}_{1}, \mathrm{EP}_{2}, \mathrm{EP}_{3}$, and $\mathrm{EP}_{4}$. During the periimplantation period $E P_{1}, E P_{3}$, and $E P_{4}$ genes are expressed in the uterus in a spatio-temporal manner, suggesting compartmentalized actions of $\mathrm{PGE}_{2}$ during this period [56]. $\mathrm{EP}_{2}$ mRNA is exclusively expressed in the luminal epithelium and appears to be involved in its differentiation for uterine receptivity. In contrast, expression of $\mathrm{EP}_{3}$ and $\mathrm{FP}$ primarily in the circular muscle of the myometrium on days 3-5 of pregnancy suggests that the circular muscle is the primary target for PG-mediated uterine contractions required for embryo transport, spacing and/or accommodation in the uterus. During postimplantation the expression of these genes in stroma appears to be associated with decidualization. $\mathrm{PGE}_{2}$ stimulates migration of extravillous trophoblast cells by signaling through $\mathrm{EP}_{1}$ receptors, increasing $\left[\mathrm{Ca}^{++}\right]_{\mathrm{I}}$, and activating calpain, a calcium-dependent protease [57].

Immunological function: $\mathrm{PGE}_{2}$ is deeply involved in the immune system and plays very important roles in $\mathrm{T}$ cell differentiation. Chizzolini and Brembilla [58] provide a concise review of the roles of $\mathrm{PGE}_{2}$ in T-cell differentiation. Upon capture of pathogens, dendritic cells release inflammatory cytokines, but $\mathrm{PGE}_{2}$ exerts an inhibitory effect by binding $\mathrm{EP}_{2}$ and $\mathrm{EP}_{4}$ on dendritic cells and inhibiting release of inflammatory cytokines [59]. $\mathrm{PGE}_{2}$ stimulates $\mathrm{T}$ helper 17 cells to expand through cAMP/PKA pathway, but $\mathrm{PGE}_{2}$ stimulates uncommitted $\mathrm{T}$ cells through $\mathrm{P} 13 \mathrm{~K}$ pathway [60]. These immunological reports are general studies using bone marrow cells, and other sources. Thus, to know exactly what happens in the pregnant uterus, uterine lymphocytes at specific stages of pregnancy may need to be used to understand the effect of $\mathrm{PGE}_{2}$ on, for example, uNK cells. Emond et al. [61] treated bovine peripheral blood lymphocytes with $\mathrm{PGE}_{2}$ and downregulated IL-2 and GM-CSF mRNA levels and found that preconditioning with $\mathrm{PGE}_{2}$ stimulates GM-CSF gene expression. They proposed that $\mathrm{PGE}_{2}$, either from embryonic or from endometrial compartments, induces bovine peripheral blood lymphocytes to undergo functional changes, affecting cellular proliferation and cytokine production in order to accommodate the developing conceptus.

\section{Anandamide}

Anandamide is an endocannabinoid neurotransmitter and has 
been found to play an important role in blastocyst implantation. Yang et al. [62] showed that mouse pre-implantation embryos contain brain-type anandamide receptor (CB1) and in vitro culture of mouse pre-implantation embryos with anandamide arrested the development of 2-cell embryos into blastocyst [63]. Schmid et al. [64] measured anandamide levels in the mouse uterus at various states of reproduction, and found that the periimplantation mouse uterus contains the highest levels among the mammalian tissues. Down-regulation of anandamide level is associated with uterine receptivity for blastocyst implantation and up-regulation is related to refractoriness. Paria et al. [65] inhibited implantation in wild type mice by maintaining high level of anandamide in the uterus. Maccarrone et al. [66] showed the activity of anandamide hydrolase in mouse uterus gradually decreases during early pregnancy and there is interplay between endocannbinoids and sex steroid hormones. Mouse blastocysts in delayed implantation remain dormant unless activated with estrogen. Wang et al. [67] found that pre-receptive uterus and dormant blastocyst contain high levels of anandamide receptor, CB1. With estrogen stimulation, $\mathrm{CB} 1$ protein levels rapidly down-regulated with the termination of delayed condition. Maccarrone et al. [68] found that mouse blstocysts secrete a lipid that activates anandamide hydrolase to reduce the anandamide concentration in the microenvironment to protect themselves. Fonseca et al. [69] studied spatio-temporal expression patters of anandamide-binding receptors in rat implantation sites and found that all three receptors [CB1, CB2 and the vanilloid receptor (TRPVI)] were expressed in decidualized cells and placenta. CB1 and CB2 were also expressed in smooth muscle cells of maternal blood vessels and endovascular trophoblast cells, whereas TRPVI was expressed in uterine natural killer (uNK) cells and in the longitudinal muscle layer throughout pregnancy. In all tissues, CB2 protein was present at a lower level than CB1.

Immunological function: Schwarz et al. [70] studied the immunoregulatory effects of anandamide and found that anandamide caused dose-dependent inhibition of mitogen-induced T and B lymphocyte proliferation. Interleukin- 6 has been reported to have many antiinflammatory and immunosuppressive effects [71]. Anandamide has been shown to influence immune reaction by enhancing IL-6 production [72]. Facci et al. [73] showed that anadamide modulated activated mast cell cytokine release. Eisenstein et al. [74] reviewed effects of cannabinoids on immune function and summarized that anadamide and THC (tetrahydrocannabinoil) and anadamide act on the immune cells via the $\mathrm{CB} 2$ receptor.

These BIEF molecules described above are only examples. I believe that the more closely we study the function of other BIEFs, the clearer the dual properties of these molecules will become evident. Researchers working on any BIEFs should integrate immune cells in their research by localizing the site of BIEF molecules of concern and identify the cells that are actually interacting with each other in that part of the implantation process.

\section{Concept 2: Conversion of the Endometrium (Uterus) from Non-privileged to Immunologically Privileged Site During Blastocyst Implantation}

Certain sites in the body are able to tolerate the introduction of antigen without an inflammatory immune response. Tissue grafts are usually recognized by the host tissue and attacked by the immune system. However, in these immunologically privileged sites grafts can survive for extended period of time without being rejected. The brain, the eye, the placenta and the fetus, and the testis are known as immunonlogically privileged sites [75]. These sites express, in common, following molecules/conditions: physical barrier, Fas-ligand, TGF- $\beta$, neuropeptide, inhibitor of complement activator and low expression of major histocompatibility complex (MHC) class Ia molecules. Described below are the reports that the early pregnant uterus indeed expresses these molecules/conditions and the uterus becomes an immunologically privileged site when it becomes receptive to accept a blastocyst to implant.

\section{Physical barrier}

Body fluid does not pass through the blood or lymphatic vessel between the immunologically privileged site and the body. Such barriers to lymphocytes are blood-brain barrier, or blood-testis barrier. Thus, a mechanical barrier surrounding the immunologically privileged sites is one of its conditions. No sooner than the embryo invades the uterine luminal epithelium is the embryo surrounded with several layers of semi-epithelialized stromal cells, primary decidual zone (PDZ), in small rodents. This zone lacks vasculature, and molecules such as immunoglobulin cannot pass through this zone [76]. Examination of para-aortic lymph nodes 4 days after mating with fertile or vasectomized males resulted in increases in cellurality regardless of the presence of sperm. This indicates the uterus is still in the condition of non-privileged site as the implantation process has barely initiated [77]. Decidualization of the mouse uterus entraps immune cells within the uterus and the lymphatic system is collapsed in the deciduas. Thus, no lymphocytes reach the efferent lymph nodes from the decidualized uterus [78]. Corneal avascularity is essential for clear view of the eye. The anterior chamber of the eye has been known as one of the immunologically privileged sites. Ambati et al. [79] showed that the cornea expresses soluble VEGF receptor-1 (sflt-1) which traps VEGF-A to maintain corneal avascularity. Neutralizing antibodies of sflt-1, RNA interference, or Cre-lox-mediated gene disruption abolishes avascularity of cornea in mice. Genetically aberrant $\mathrm{Paxo}^{+/-}$mice or $\mathrm{Paxo}^{+/-}$patients with aniridia are deficient in sflt-1, and recombinant sflt-1 administration abolishes vascularity. Thus, these researchers provide insights into the molecular mechanism of the anterior chamber of the eye as the immunologically privileged site. Just like the anterior chamber of the eye, the primary decidual zone and decidualized mouse uterus clearly present the mechanical barrier to immune cells and/or immunoglobulin, and thus are qualified as immunologically privileged sites. Although this barrier formation is obvious in the rat and mouse, there is considerable development of intra-endometrial trophoblast before decidualization is extensive in the guinea pig, human and macaque.

\section{Fas Ligand expression}

Fas ligand (FasL) is a member of the TNF family and it, upon binding to Fas receptor on target cells, induces apoptosis, programmed death. Thus, FasL restricts immigration of activated lymphocytes into the immunologically privileged sites such as testis, the anterior 
chamber of the eye, by delivering a death signal to the lymphocytes through their Fas receptors. Cells express FasL on their surface, which binds to cytotoxic T cells and causes them to apoptose rather than destroy the tissue of privileged sites. Hunt et al. [80] observed immunoreactive FasL was prominent in glandular and decidual cells between day 6 and 10 of pregnancy in the mouse. FasL was expressed in placental trophoblast cells bordering maternal blood spaces and fetal endothelial cells between day 12 and 14. Thus, FasL is appropriately positioned to defer trafficking of activated Fas + immune cells between the mother and the embryo/ fetus. They also observed reduced fertility in a mutant strain of mice lacking functional FasL. Makrigiannakis et al. [81] also found that CRH stimulates isolated human extravillous trophoblast and JEG3 cells to express FasL in vitro, suggesting that $\mathrm{CRH}$ supports implantation of embryos by expressing FasL sourrounding the implanting embryos. In humans, Ohshima et al. [82] studied early pregnancy curettage uterine contents and found the expression of FasL and RCAS1 (receptor-binding cancer antigen expressed on SiSo cells) was strikingly decreased in cases where uterine bleeding and abortion occurred. RCAS1 has been recognized to play a role in immune evasion of the tumor cells. Selam et al. [83] showed up-regulation of FasL in human endometrium by estradiol and progesterone. Kasyisli et al. [30] demonstrated that hCG stimulates FasL mRNA and protein in endometrial cells, and observed that cells of early pregnancy deciduas express strong FasL immunoreactivity. They thought that hCG may be a link in the development of peritrophoblastic immune tolerance and may facilitate the trophoblast invasion by regulating proapoptotic molecules such as FasL in endometrial cells. These reports qualify early pregnant uterus having one of the conditions of the immunologically privileged site.

\section{TGF- $\beta$ expression}

Immune response is modified by the privileged sites through antiinflammatory cytokine release of TGF- $\beta$, which suppresses immune responses that may cause tissue damage. Local production of TGF- $\beta$ is one of the common features of immunologically privileged sites. Tamada et al. [84] determined temporal and spatial expression of TGF- $\beta 1$ in the mouse uterus during peri-implantation period by using the polyclonal antibodies against two different preparations of TGF- $\beta 1$ which primarily stain extracellular and intracellular TGF- $\beta 1$ respectively. These investigators found that the luminal and glandular epithelial cells are primary sites of TGF- $\beta 1$ synthesis during preimplantation (dayl-4 of pregnancy) period, the extracellular staining of TGF- $\beta 1$ appeared on day 3 and markedly increased on day 4 when the invasion of the luminal epithelium takes place in the evening of that day. While intracellular staining was restricted to the luminal epithelium and primary decidual zone (PDZ), intense extracellular staining was noted in the decidualizing stroma around the PDZ and the extracellular staining persisted in the secondary decidual zone and decidua capsularis at later stages. Moulton [85] showed that TGF- $\beta 2$ controls apoptosis in endometrial stromal cells in vitro by an autocrine/paracrine mechanism and suggested that this mechanism controls apoptosis in these cells during early pregnancy. In the human, the endometrial stromal cells decidualize during late luteal phase and continue during pregnancy. One of the most distinctive features of decidualization is the appearance of a large population of decidual natural killer (dNK) cells. As $\mathrm{dNK}$ cells reside in close cell-to-cell contact with decidual cells, Keskin et al. [86] examined if TGF- $\beta$ had any effects on immune cells. They incubated NK cells of peripheral blood with TGF- $\beta 1$, or with conditioned medium with decidual cells, and found that $\mathrm{CD}^{-} 6^{+} \mathrm{CD} 9^{-}$cells were transitioned to $\mathrm{CD} 16^{-} \mathrm{CD}^{+}$, resembling decidual NK cells. These reports support the notion that TGF- $\beta$ plays an important role in the immunologically privileged sites by protecting against any damages that might occur by invasion of hostile immune cells.

\section{Expression of neuropeptides}

Makrigiannakis et al. [87] showed that early pregnant uterine luminal epithelium and deciduas at implanation sites expressed corticotrophin-releasing hormone $(\mathrm{CRH})$. As already stated in the section on FasL section, CRH stimulates expression of FasL. The decidua has been shown to express a number of neuropeptides such as neuropeptide Y (NPY) [88], vaso-active intestinal peptide [89], NPY-R [90], prolactin-releasing peptide (Prl-RP) and its receptor [91], ghrelin [92], tachykins [93]. Whether these neuropeptides have all immune-modulatory effects are not clear. Some peptides have opposite effects on the immune system and they may work as adjustment tools of the local immune environment. These reports support the fact that the early pregnant uterus expresses neuropeptides and thus, satisfies this condition as an immunologically privileged site. Ghrelin is a 28 -amino acid peptide found in hypothalamus and stomach, but it has many physiological functions. It stimulates decidualization of stromal cells in vitro, and this molecule has been localized in decidual cells and extravillous trophoblast cells [92].

\section{Expression of inhibitors of complement activators}

Inhibition of complement activators is important in preventing antigen-antibody reactions. Thus expression of such a complement regulatory protein [e.g., decay-accelerating factor (DAF; or CD55), membrane cofactor protein (MCP, or CD 46), and membrane inhibitor of reactive lysis (MIRL, or CD59)] is one of the conditions of an immunologically privileged site. The menstrual physiology involving insufficient or truncated development of the secretory endometrium is termed "luteal phase defect", and is usually associated with decreased progesterone levels. Kaul et al. [94] found decreased expression of endometrial DAF in patients with luteal phase defect. Xu et al. [95] generated mice with a disrupted gene for the complement regulator, Crry, and found that $\mathrm{Crry}^{-/-}$embryos did not survive because of complement deposition and concomitant placental inflammation. Thus, the regulation of complement is critical in fetal control of maternal processes that mediate tissue damage. Young et al. [96] found that DAF is expressed predominantly in the apical membrane of glandular and luminal epithelium. DAF expression was minimal in the proliferative and early secretory phases, and increased markedly on approximately day $\mathrm{LH}+7$ (lumen) and $\mathrm{LH}+8$ (glands), and persistent into menses. DAF is stimulated by HB-EGF or other EGF family members and may function to protect the epithelial integrity of human endometrium in the face of increased complement expression. These reports support the fact that the uterus under the influence of progesterone expresses 
complement regulatory protein such as DAF and thus, satisfies this condition as a immunologically privileged site.

\section{Low expression of classical MHC Ia molecules}

The classical MHC class I molecules are expressed on most somatic cells and present peptides to cytotoxic lymphocytes. As expression of these molecules would invite cytoxic lymphocytes, it is desirable for the immune privileged sites to avoid expression of these molecules. Choi et al. [97] studied expression of MHC class I $\alpha$ chain and $\beta_{2}$-microglobulin genes in the ovine uterus. During pregnancy, expression of these genes is inhibited in endometrial luminal epithelium and surface glandular epithelium, but their expression was stimulated by IFN- $\tau$ in the stroma and glandular epithelium. This appears to be a critical mechanism preventing immune rejection of the conceptus allograft. Joyce et al. [98] examined these molecules that are recognized by immune cells as inappropriate for "immunologically privileged site" on the pregnant porcine uterine luminal epithelial surface. The molecules they examined were the classical class I swine leukocyte antigen (SLA) genes: $S L A-1, S L A-2$, and $S L A-3$, the nonclassical genes: $S L A-6$, $S L A-7$, and $S L A-8$, and $\beta_{2}$-microglobulin $\left(\beta_{2}-\mathrm{m}\right)$ gene. Uterine SLA and $\beta_{2}-\mathrm{m}$ increased between day 5 and 9 , then decreased between day 15 and 20. By day 15 of pregnancy SLA and $\beta_{2}-\mathrm{m}$ increased in stroma. These studies support the assumption that pregnant uterine luminal surface satisfies this low expression of classical MHC molecules condition as the immunologically privileged site.

The above reports clearly demonstrate that the early pregnant endometrium is being converted immunologically to a privileged site. When we obtain detailed data on these molecules/conditions during the process of implantation, we can map the expression of these molecules/conditions in various locations. By following these locations throughout the process of implantation we can visualize how the immunological conversion takes place.

At the time of mating, the uterus of a rat is not immunologically privileged site. However, progesterone secretion increase from newly formed corpora lutea of pregnancy together with a small increase in estrogen in the afternoon of day 4 of pregnancy make the uterus receptive. Thus, inoculation of Walkers carcinosarcoma cells into the uterine lumen do not let the tumor cells grow when inoculated at any day of the estrous cycle, except for day 5 of speudopregnancy or under the steroid hormone regimen designed to make the uterus receptive [99]. The results of this study may well be explained by immunological rejection/take of these inoculated tumor cells by the uterus.

In conclusion, I have presented two concepts that the implantation process involves both physiological/endocrinological and immunological aspects. Studying implantation by a multi-disciplinary approach will allow us to understand when and where specific BIEFs should be expressed. This may lead to the development of a diagnostic method for infertility caused by implantation failure. Once a reliable diagnostic method is established, treatment of infertility caused by implantation failure will be within our reach.

\section{Acknowledgments}

The author expresses his sincere thanks to Dr AC Enders of Uni- versity of California Davis, and to Dr M PrabhuDas of NIAID, NIH for kindly reading the manuscript and for their valuable suggestions and comments.

\section{References}

1. Yoshinaga K. Review of factors essential for blastocyst implantation for their modulating effects on the maternal immune system. Semin Cell Dev Biol 2008; 19: 161-169. [Medline] [CrossRef]

2. Graham JD, Clarke CL. Physiological action of progesterone in target tissues. Endocr Rev 1997; 18: 502-519. [Medline] [CrossRef]

3. Spencer TE, Bazer FW. Biology of progesterone action during pregnancy recognition and maintenance of pregnancy. Front Biosci 2002; 7: d1879-1898.

4. Large MJ, Demayo FJ. The regulation of embryo implantation and endometrial decidualization by progesterone receptor signaling. Mol Cell Endocrinol 2011; doi: 10.1016/j.mce.2011.07.027 [CrossRef]. [Medline]

5. Psychoyos A. Endocrine control of egg implantation. In: Greep RO, Astwood EB (eds.), Handbook of Physiology.Washington, DC: American Physiological Society: 1973; 187-215.

6. Ma WG, Song H, Das SK, Paria BC, Dey SK. Estrogen is a critical determinant that specifies the duration of the window of uterine receptivity for implantation. Proc Nat Acad Sci 2003; 100: 2963-2968. [Medline] [CrossRef]

7. Daynes RA, Meikle AW, Araneo BA. Locally active steroid hormones may facilitate compartmentalization of immunity by regulating the types of lymphokines produced by helper T cells. Res Immunol 1991; 142: 40-45. [Medline] [CrossRef]

8. Piccinni M-P, Giudizi M-G, Biagiotti R, Beloni L, Giannarini L, Sampognaro S, Parronchi P, Manetti R, Annunziato F, Livi C, Romagnani S, Maggi E. Progesterone favors the development of human $\mathrm{T}$ helper cells producing Th-2-type cytokines and promotes both IL-4 production andmembrane CD30 expression in established Th1 cell clones. J Immunol 1995; 155: 128-133. [Medline]

9. Miyaura H, Iwata M. Direct and indirect inhibition of Th1 development by progesterone and glucocorticoids. J Immunol 2002; 168: 1087-1094. [Medline]

10. Dosiou C, Hamilton AE, Pang Y, Overgaard MT, Tulac S, Dong J, Thomas $\mathbf{P}$, Giudice LC. Expression of membrane progesterone receptors on human T lymphocytes and Jurkat cells and activation of G-proteins by progesterone. J Endocr 2008; 196: 67-77. [Medline] [CrossRef]

11. Laskarin G, Tokmadzic VS, Strbo N, Bogovic T. szekeres-Bartho J, Randic L, Podack ER, Rukavina D. Progesterone induced blocking factor (PIBF) mediates progesterone induced suppression of decidual lymphocyte cytotoxicity. Am J Reprod Immunol 2002; 48: 201-209. [Medline] [CrossRef]

12. Hirose T. On artificial production of corpola letea in the rabbit ovary. Journal of Japanese Obstetrical Society 1920; 16: 1153-1178. (In Japanese).

13. Strott CA, Yoshimi T, Ross GT, Lipsett MB. Ovarian physiology: relationship between plasma LH and steroidogenesis by the follicle and copus luteum; effect of HCG. J Clin Endocrinol Metab 1969; 29: 1157-1167. [Medline] [CrossRef]

14. Shi QJ, Lei ZM, Rao CV, Lin J. Novel role of human chorionic gonadotropin in differentiation of human cytotrophoblasts. Endocrinology 1993; 132: 1387-1395. [Medline] [CrossRef]

15. Islami D, Bischof $\mathbf{P}$, Chardonnens $\mathbf{D}$. Modulation of placental vascular endothe lial growth factor by leptin and hCG. Mol Hum Reprod 2003; 9: 395-398. [Medline] [CrossRef]

16. Berndt S, Blacher S, d'Hauterive SP, Thiry M, Tsampalas M, Cruz A, Pequeux C, Lorquet S, Munaut C, Noel A, Foidart J-M. Chorionic gonadotropin stimulation of angiogenesis and pericyte recruitment. J Clin Endocrinol Metab 2009; 94: 4567-4574. [Medline] [CrossRef]

17. North RA, Whitehead R, Larkins RG. Stimulation by human chorionic gonadotropin of prostaglandin synthesis by early human placental tissue. J Clin Endocrinol Metab 1991; 73: 60-70. [Medline] [CrossRef]

18. Menon KMJ, Jaffe RB. Chorionic gonadotropin-sensitive adenylate cyclase in human term placenta. J Clin Endocrinol Metab 1973; 36: 1104-1109. [Medline] [CrossRef]

19. Hermann-Lavoie C, Rao CV, Akoum A. Chorionic gonadotropin down-regulates the expression of the decoy inhibitory interleukin receptor type II in human endometrial epithelial cells. Endocrinology 2007; 148: 5377-5384. [Medline] [CrossRef]

20. d'Hauterive SP, Charlet-Renaurd C, Berndt S, Dubois M, Munaut C, Goffin F, Hagelstein M-T, Noel A, Hazout A, Foidart J-M, Geenen V. Human chorionic gonadotropin and growth factors at the embryonic-endometrial interface control leukemia inhibitory factor (LIF) and interleukin 6 (IL-6) secretion by human endometrial epithelium. Human Reprod 2004; 19: 2633-2643. [CrossRef]

21. Cole HH, Hart GH. The potency of blood serum of mares in progressive stages of 
pregnancy in effecting the sexual maturity of the immature rat. Am J Physiol 1930; 93: $57-68$.

22. Stewart F, Allen WR. Biological functions and receptor binding activities of equine chorionic gonadotrophins. J Reprod Fertil 1981; 62: 527-536. [Medline] [CrossRef]

23. Short RV. Progesterone in blood. IV. Progesterone in the blood of mare. J Endocrinol 1959; 19: 207-210. [Medline] [CrossRef]

24. Moor RM, Rowson LEA. Local uterine mechanisms affecting luteal function in the sheep. J Reprod Fert 1966; 11: 307-310. [CrossRef]

25. Rowson LEA, Moor RM. The influence of embryonic tissue homogenate infused into the uterus, on the life-span of the corpus luteum in the sheep. J Reprod Fertil 1967; 13: 511-516. [Medline] [CrossRef]

26. Imakawa K, Anthony RV, Kazemi M, Marotti KR, Polites HG, Roberts RM. Interferon-like sequence of ovine trophoblast protein secreted by embryonic trophectoderm. Nature 1987; 330: 377-379. [Medline] [CrossRef]

27. Roberts RM, Cross JC, Leaman DW. Interferons as hormones of pregnancy. Endocr Rev 1992; 13: 432-452. [Medline]

28. Roberts RM, Chen Y, Ezashi T, Walker AM. Interferons and the maternal-conceptus dialog in mammals. Semin Cell Dev Biol 2008; 19: 170-177. [Medline] [CrossRef]

29. Johnson GA, Spencer TE, Burghardt RC, Bazer FW. Ovine osteopontin: I. cloning and expression of messenger ribonucleic acid in the uterus during the periimplantation period. Biol Reprod 1999; 61: 884-891. [Medline] [CrossRef]

30. Kayisli UA, Selam B, Guzeloglu-Kayisli O, Demir R, Arici A. Human chorionic gonadotropin contributes to maternal immunotolerance and endometrial apoptosis by regulating Fas-Fas ligand system. J Immunol 2003; 171: 2305-2313. [Medline]

31. Akoum A, Metz CN, Morin M. Marked increase in macrophage migration inhibitory factor synthesis and secretion in human endometrial cells in response to human chorionic gonadotropin hormone. J Clin Endocrinol Metab 2005; 90: 2904-2910. [Medline] [CrossRef]

32. Wan H, Versnel MA. Cheung Wy, Leenen PJM, Khan NA, Benner R, Klekens CM. Chorionic gonadotropin can enhance innate immunity by stimulating macrophage function. J Leukoc Biol 2007; 82: 926-933. [Medline] [CrossRef]

33. Ueno A, Cho S, Cheng L, Wang J, Hou S, Nakano H, Santamaria P, Yang Y. Transient upregulation of indoleamine2,3dioxygenase in dendritic cells by human chorionic gonadotropin down regulates autoimmune diabetes. Diabetes 2007; 56: 1686-1693. [Medline] [CrossRef]

34. Lei ZM, Yang M, Li X, Takikawa O, Rao CV. Upregulation of placental indoleamine 2,3-dioxygenase by human chorionic gonadotropin. Biol Reprod 2007; 76: 639-644. [Medline] [CrossRef]

35. Wan H, Versnel MA, Leijten LME, van Helden-Meeuwsen CG, Fekkes D, Leenen PJM, Khan NA, Benner R. Chorionic gonadotropin induces dendritic cells to express a tolerogenic phenotype. J Leukoc Biol 2008; 83: 894-901. [Medline] [CrossRef]

36. Kane N, Kelly R, Saunders PTK, Critchley HOD. Proliferation of uterine natural killer cells is induced by hCG via the mannose receptor. Endocrinology 2009; 150: 2882-2888. [Medline] [CrossRef]

37. Emond V, Asselin E, Fortier MA, Murphy BD, Lambert RD. Interferon-tau stimulates granulocyte-macrophage colony-stimulating factor gene expression in bovine lymphocytes and endometrial stromal cells. Biol Reprod 2000; 62: 1728-1737. [Medline] [CrossRef]

38. Garcia-Lloret MI, Morrish DW, Wegmann TG, Honore L, Turner AR, Guilbert LJ. Demonstration of functional cytokine-placental interactions: CSF-1 and GMCSF stimulate human cytotrophoblast differentiation and peptide hormone secretion. Exp Cell Res 1994; 214: 46-54. [Medline] [CrossRef]

39. Emond V, MacLaren LA, Kimmins S, Arosh JA, Fortier MA. Expression of cyclooxygenase-2 and granulocyte-macrophage colony-stimulating factor in the endometrial epithelium of the cow is up-reulated during early pregnancy and in response to intrauterine infusions of interferon- $\tau$. Biol Reprod 2004; 70: 54-64. [Medline] [CrossRef]

40. de Moraes AAS, Hansen PJ. Granulocyte-macrophage coloney-stimulating factor promotes development of in vitro produced bovine embryos. Biol Reprod 1997; 57: 1060-1065. [Medline] [CrossRef]

41. Stewart CL, Kaspar P, Brunet L, Bhatt H, Gadi I, Kontgen F, Abbondanzo SJ. Blastocyst implantation depends on maternal expression of leukemia inhibitory factor. Nature 1992; 359: 76-79. [Medline] [CrossRef]

42. Song H, Lim H, Das SK, Paria BC, Dey SK. Dysregulation of EGF family of growth factors and COX-2 in the uterus during the preattachment and attachment reactions of the blastocyst with the luminal epithelium correlates with implantation failure in LIF-deficient mice. Mol Endocrinol 2000; 14: 1147-1161. [Medline] [CrossRef]

43. Cheng J-G, Chen JR, Hernandez L, Alvord WG, Steart CL. Dual control of LIF expression and LIF receptor function regulate Stat3 activation at the onset of uterine receptivity and embryo implantation. Proc Nat Acad Sci 2001; 98: 8680-8685. [Medline] [CrossRef]
44. Arici A. J Engin O, Attar E, Olive DL. Modulation of leukemia inhibitory factor gene expression and protein biosynthesis in human endometrium. J Clin Endocrinol Metab 1995; 80: 1908-1915. [Medline] [CrossRef]

45. Aghajanova L, Stavreus-Evers A, Nikas Y, Hovatta O, Landgren B-M. Coexpression of pinopodes and leukemia inhibitory factor, as well as its receptor, in human endometrium. Fertil Steril 2003; 79: 808-814. [Medline] [CrossRef]

46. Marwood M, Visser K, Salamonsen LA, Dimitriadis E. Interleukin-11 and leukemia inhibitory factor regulate the adhesion of endometrial epithelial cells: implications in fertility regulation. Endocrinology 2009; 150: 2915-2923. [Medline] [CrossRef]

47. Takahashi Y, Takahashi M, Carpino N, Jou S-T, Chao J-R, Tanaka S, Shigeyoshi Y, Parganas E, Ihle JN. Leukemia inhibitory factor regulates trophoblast giant cell differentiation via Janus kinase 1-signal transducer and activator of transcription 3-suppressor of cytokine signaling 3 pathway. Mol Endocrinol 2008; 22: 1673-1681. [Medline] [CrossRef]

48. Kimber SJ. Leukemia inhibitory factor in implantation and uterine biology. Reproduction 2005; 130: 131-145. [Medline] [CrossRef]

49. Schofield G, Kimber SJ. Leukocyte subpopulations in the uteri of leukemia inhibitory factor knockout mice during early pregnancy. Biol Reprod 2005; 72: 872-878. [Medline] [CrossRef]

50. Metcalfe SuM, Watson TJ, Shurey S, Adams E, Green CJ. Leukemia inhibitory factor is linked to regulatory transplantation tolerance. Transplantation 2005; 79: 726-730. [Medline] [CrossRef]

51. McMaster MT, Librach CL, Zhou Y, Lim K-H, Janatpour MJ, DeMars R, Kovats S, Damsky C, Fisher SJ. Human placental HLA-G expression is restricted to differentiated cytotrophoblasts. J Immunol 1995; 154: 3771-3778. [Medline]

52. Bamberger A-M, Jenatschke S, Schulte HM, Loning T, Bamberger CM. Leukemia inhibitory factor (LIF) stimulates the human HLA-G promoter in JEG3 choriocarcinoma cells. J Clin Endocrinol Metab 2000; 85: 3932-3936. [Medline] [CrossRef]

53. Kennedy TG. Evidence for a role for prostaglandins in the initiation of blastocyst implantation in the rat. Biol Reprod 1977; 16: 286-291. [Medline] [CrossRef]

54. Frank GR, Brar AK, Cedars MI, Handwerger S. Prostaglandin $E_{2}$ enhances human endometrial stromal cell differentiation. Endocrinology 1994; 134: 258-263. [Medline] [CrossRef]

55. Lim H, Dey SK. Prostaglandin $\mathrm{E}_{2}$ receptor subtype $\mathrm{EP}_{2}$ gene expression in the mouse uterus coincides with differentiation of the luminal epithelium for implantation. Endocrinology 1997; 138: 4599-4606. [Medline] [CrossRef]

56. Yang ZM, Das SK, Wang J, Sugimoto Y, Ichikawa A, Dey SK. Potential sites of prostaglandin actions in the periimplantation mouse uterus: differential expression and regulation of prostaglandin receptor genes. Biol Reprod 1997; 56: 368-379. [Medline] [CrossRef]

57. Nicola C, Timoshenko AV, Dixon SJ, Lala PK, Chakraborty C. EP1 receptormediated migration of the first trimester human extravillous trophoblast: the role of intracellular calcium and calpain. J Clin Endocrinol Metab 2005; 90: 4736-4746. [Medline] [CrossRef]

58. Chizzolini C, Brembilla NC. Prostaglandin E2: igniting the fire. Immunol Cell Biol 2009; 87: 510-511. [Medline] [CrossRef]

59. Jing H, Vassiliou E, Ganea D. Prostaglandin E2 inhibits production of the inflammatory chemokines CCL3 and CCL4 in dendritic cells. J Leukoc Biol 2003; 74: 868879. [Medline] [CrossRef]

60. Yao C, Sakata D, Esaki Y, Li Y, Matsuoka T, Kuroiwa K, Sugimoto Y, Narumiya S. Prostaglandin $E_{2}$-EP4 signaling promotes immune inflammation through $T_{H} 1$ cell differentiation and $\mathrm{T}_{\mathrm{H}} 17$ cell expansion. Nat Med 2009; 15: 633-640. [Medline] [CrossRef]

61. Emond V, Fortier MA, Murphy BD, Lambert RD. Prostaglandin $E_{2}$ regulates both interleukin-2 and granulocyte-macrophage Colony-stimulating factor gene expression in bovine lymphocytes. Biol Reprod 1998; 58: 143-151. [Medline] [CrossRef]

62. Yang Z-M, Paria BC, Dey SK. Activation of brain-type cannabinoid receptors interferes with preimplantation mouse embryo development. Biol Reprod 1996; 55: 756-761. [Medline] [CrossRef]

63. Paria BC, Das SK, Dey SK. The preimplantation mouse embryois a target for cannabinoid ligand-receptor signaling. Proc Nat Acad Sci 1995; 92: 9460-9464. [Medline] [CrossRef]

64. Schmid PC, Paria BC, Krebsbach RJ, Schmid HH, Dey SK. Changes in anandamide levels in mouse uterus are associated with uterine receptivity for embryo implantation. Proc Nat Acad Sci 1997; 94: 4188-4192. [Medline] [CrossRef]

65. Paria BC, Song H, Wang X, Schmid PC, Krebsbach RJ, Schmid HHO, Bonner TI, Zimmer A, Dey SK. Dysregulated cannabinoid signaling disrupts uterine receptivity for embryo implantation. J Biol Chem 2001; 276: 20523-20528. [Medline] [CrossRef]

66. Maccarrone M, De Felici M, Bari M, Klinger F, Siracusa G, Finazzi-Agro A. 
Down-regulation of anadamide hydrolase in mouse uterus by sex hormones. Eur $J$ Biochem 2000; 267: 2991-2997. [Medline] [CrossRef]

67. Wang H, Matsumoto H, Guo Y, Paria BC, Roberts RL, Dey SK. Differential G protein-coupled cannabinoid receptor signaling by anadamide directs blastocyst activation for implantation. Proc Nat Acad Sci 2003; 100: 14914-14919. [Medline] [CrossRef]

68. Maccarrone M, DeFelici M, Klinger FG, Battista N, Fezza F, Dainese E, Siracusa G, Finazzi-Agro A. Mouse blastcysts release a lipid which activates anadamide hydrolase in intact uterus. Mol Human Reprod 2004; 10: 215-221. [CrossRef]

69. Fonseca BM, Correia-da-Silva G, Taylor AH, Konje JC, Bell SC, Teixeira NA. Spatio-temporal expression patterns of anandamide-binding receptors in rat implantation sites: evidence for a role of the endocannabinoid system during the period of placental development. Reprod Biol Endocrinol 2009; 7: 121-133. [Medline] [CrossRef]

70. Schwarz H, Blanco FJ, Lotz M. Anadamide, an endogenous cannabinoid receptor agonist inhibits lymphocyte proliferation and induces apoptosis. J Neuroimmunol 1994; 55: 107-115. [Medline]

71. Xing Z, Gauldie J, Cox G, Baumann H, Jordana M, Lei X-F, Achong MK. IL-6 is an anti-inflammatory cytokine required for controlling local or systemic acute inflammatory responses. I Clin Invest 1998; 101: 311-320. [CrossRef]

72. Molina-Holgado F, Molina-Holgado E, Guaza C. The endogenous cannabinoid anadamide potentiates interleukin- 6 production by astrocytes infected with Theiter's murine encephalomyelitis virus by a receptor-mediated pathway. FEBS Let 1998; 433: 139-142. [CrossRef]

73. Facci L, Toso RD, Romanello S, Buriani A, Skaper SD, Leon A. Mast cells express a peripheral cannabinoid receptor with differential sensitivity to anadamide and palmitoylethanolamide. Proc Nat Acad Sci 1995; 92: 3376-3380. [Medline] [CrossRef]

74. Eisenstein TK, Meissler JJ Jr, Wilson Q, Gaughan JP, Adler MW. Anadamide and $\Delta^{9}$-tetrahydrocannabinoil directly inhibit cells of the immune system via CB2 receptor. J Neuroimmunol 2007; 189: 17-22. [Medline] [CrossRef]

75. Janeway CA, Travers $\mathbf{P}$, Walport M, Shlomchik MJ. Immunobiology. $6^{\text {th }}$ ed, New York: Garland Science Publishing, 2005.

76. Tung HN, Parr MB, Parr EL. The permeability of the primary decidual zone in the rat uterus: An untrastructural tracer and freeze-fracture study. Biol Reprod 1986; 35: 1045-1058. [Medline] [CrossRef]

77. Johansson M, Bromfield JJ, Jasper MJ, Robertson SA. Semen activates the female immune response during early pregnancy in mice. Immunology 2004; 112: 290-300. [Medline] [CrossRef]

78. Collins MK, Tay C-S, Erlebacher A. Dendritic cell entrapment within the pregnant uterus inhibits immune surveillance of the maternal/fetal interface in mice. $J$ Clin Invest 2009; 119: 2062-2073. [Medline]

79. Ambati BK, Nozaki M, Singh N, Takeda A, Jani PD, Suthar T, Albuquerque RJC, Richter E, Sakurai E, Newcomb MT, Kleinman ME, Caldwell RB, Lin Q, Ogura Y, Orecchia A, Samuelson DA, Agnew DW, St. Leger J, Green WR, Mahasreshti PJ, Curiel DT, Kwan D, Marsh H, Ikeda S, Leiper LJ, Collinson JM, Bogdanovich S, Khurana TS, Shibuya M, Baldwin ME, Ferrara N, Gerber H-P, De Falco S, Witta J, Baffi JZ, Raisler BJ, Ambati J. Corneal avascularity is due to soluble VGEF receptor-1. Nature 2006; 443: 993-997. [Medline] [CrossRef]

80. Hunt JS, Vassmer D, Ferguson TA, Miller L. Fas ligand is positioned in mouse uterus and placenta to prevent trafficking of activated leukocytes between the mother and the conceptus. J Immunol 1997; 158: 4122-4128. [Medline]

81. Makrigiannakis A, Zouromakis E, Kalantaridou S, Coutifaris C, Margioris AN, Coukos G, Rice KC, Gravanis A, Chrousos GP. Corticotropin-releasing hormone promotes blastocyst implantation and maternal early tolerance. Nat Immunol 2001; 2: 1018-1024. [Medline] [CrossRef]

82. Ohshima K, Nakashima M, Sonoda K, Kikuchi M, Watanabe T. Expression of RCAS1 and FasL in human trophoblasts and uterine glands during pregnancy: the possible role in immune privilege. Clin Exp Immunol 2001; 123: 481-486. [Medline] [CrossRef]

83. Selam B, Kayisli UA, Mulayim N, Arici A. Regulation of Fas ligand expression by estradiol and progesterone in human endometrium. Biol Reprod 2001; 65: 979-985. [Medline] [CrossRef]

84. Tamada H, McMaster MT, Flanders KC, Andrews GK, Dey SK. Cell type-specific expression of transforming growth factor- $\beta 1$ in the mouse uterus during periimplantation period. Mol Endocrinol 1990; 4: 965-972. [Medline] [CrossRef]

85. Moulton BC. Transforming growth factor-beta stimulates endometrial apoptosis in vitro. Endocrinology 1994; 134: 1055-1060. [Medline] [CrossRef]

86. Keskin DB, Allan DSJ, Rybalov B, Andzelm MM, Stern JNH, Kopcow HD, Koopman LA, Strominger JL. TGF $\beta$ promotes conversion of $\mathrm{CD}_{1} 6^{+}$peripheral blood NK cells into CD16- NK cells with similarities to decidual NK cells. Proc Nat Acad Sci 2007; 104: 3378-3383. [Medline] [CrossRef]

87. Makrigiannakis A, Margioris AN, Le Goascogne C, Zoumakis E, Nikas G, Stoumaras C, Psychoyos A, Gravanis A. Corticotropin-releasing hormone (CRH) is expressed at the implantation sites of early pregnant rat uterus. Life Sci 1995; 57: 1869-1875. [Medline] [CrossRef]

88. Petraglia F, Calzs L, Giardino L, Zanni M, Florio P, Ferrari AR, Nappi C, Genazzani AR. Maternal deciduas and fetal membranes contain immunoreactive neuropeptide Y. J Endocrinol Invest 1993; 16: 201-205. [Medline]

89. Spong CY, Lee SJ, McCune SK, Cibney G, Abebe DT, Alvero R, Brenneman DE, Hill JM. Maternal regulation of embryonic growth: therole of vasoactive intestina peptide. Endocrinology 1999; 140: 917-924. [Medline] [CrossRef]

90. Chen H-W, Chen JJW, Tzeng C-R, Li HN, Chang S-J, Cheng YF, Chang CW, Wang R-S, Yang PC, Lee YT. Global analysis of differentially expressed genes in early gestational deciduas and chorionic villi using a 9600 human cDNA microarray. Mol Human Reprod 2002; 8: 475-484. [CrossRef]

91. Reis FM, Vigano P, Arnaboldi E, Spritzer PM, Petraglia F, Di Blasio M. Expression of prolactin-releasing peptide and its receptor in the human deciduas. $\mathrm{Mol} \mathrm{Hu}$ man Reprod 2002; 8: 356-362. [CrossRef]

92. Tanaka K, Minoura H, Isobe T, Yonaha H, Kawato H, Wang DF, Yoshida T, Kojima M, Kangawa K, Toyoda N. Ghrelin is involved in the decidualization of human endometrial stromal cells. J Clin Endocr Metab 2003; 88: 2335-2340. [Medline] [CrossRef]

93. Patak E, Candenas L, Pennefather JN, Zicconne S, Lilley A, Martin JD, Flores C, Mantecon AG, Story ME, Pinto FM. Tachykinins and tachykinin receptors in human uterus. Br J Pharmacol 2003; 139: 523-532. [Medline] [CrossRef]

94. Kaul A, Nagamani M, Nowicki B. Decreased expression of endometrial decay accelerating factor (DAF), a complement regulatory protein, in patients with luteal phase defect. Am J Reprod Immunol 1995; 34: 236-240. [Medline]

95. Xu C, Mao D, Holers VM, Palanca B, Cheng AM, Molina H. A critical role for murine complement regulator Crry in fetomaternal tolerance. Science 2000; 287 498-501. [Medline] [CrossRef]

96. Young SL, Lessey BA, Fritz MA, Meyer WR, Murray MJ, Speckman PL, Nowicki BJ. In vivo and in vitro evidence suggest that HB-EGF regulates endometrial expression of human decay accelerating factor. J Clin Endocrinol Metab 2002; 87: 1368-1375. [Medline] [CrossRef]

97. Choi Y, Johnson GA, Spencer TE, Bazer FW. Pregnancy and interferon tau regulate major histocompatibility complex class I and $\beta_{2}$-microglobulin expression in the ovine uterus. Biol Reprod 2003; 68: 1703-1710. [Medline] [CrossRef]

98. Joyce MM, Burghardt JR, Burghardt RC, Hooper RN, Bazer FW, Johnson GA. Uterine MHC Class I molecules and $\beta_{2}$-microglobulin are regulated by progesterone and conceptus interferons during pig pregnancy. J Immunol 2008; 181: 2494-2505. [Medline]

99. Short RV, Yoshinaga K. Hormonal influences on tumour growth in the uterus of the rat. J Reprod Fert 1967; 14: 287-293. [CrossRef] 